\title{
Risk factors for mortality in blunt abdominal trauma with surgical approach
}

\author{
Fatores de risco para óbito no trauma abdominal fechado com abordagem \\ cirúrgica
}

Silvania Klug Pimentel, TCBC-PR'; Gullherme Vinicius Sawczyn²; Melissa Mello Mazepa 3; Felipe Guilherme Gonçalves da Rosa3; Adonis Nars, TCBC-PR'; Iwan Augusto Collaço, TCBC-PR²

\section{A}

\begin{abstract}
Objective: identify risk factors for mortality in patients who underwent laparotomy after blunt abdominal trauma. Methods: retrospective study, case-control, which were reviewed medical records of blunt trauma victims patients undergoing laparotomy, from March 2013 to January 2015, and compared the result of the deaths group with the group healed. Results: of 86 patients, $63 \%$ were healed, $36 \%$ died, and one patient was excluded from the study. Both groups had similar epidemiology and trauma mechanism, predominantly young adults males, automobilistic accident. Most cases that evolved to death had hemodynamic instability as laparotomy indication - $61 \%$ against $38 \%$ in the other group $(p=0.02)$. The presence of solid organ injury was larger in the group of deaths $-80 \%$ versus $48 \%(p=0.001)$ and $61 \%$ of them had other associated abdominal injury compared to $25 \%$ in the other group $(p=0.01)$. Of the patients who died $96 \%$ had other serious injuries associated $(p=0.0003)$. Patients requiring damage control surgery had a higher mortality rate $(p=0.0099)$. Only one of 18 patients with isolated hollow organ lesion evolved to death $(p=0.0001)$. The mean injury score of TRISS of cured $(91.70 \%)$ was significantly higher than that of deaths $(46.3 \%)$ $(p=0.002)$. Conclusion: the risk factors for mortality were hemodynamic instability as an indication for laparotomy, presence of solid organ injury, multiple intra-abdominal injuries, need for damage control surgery, serious injury association and low index of trauma score.
\end{abstract}

Key words: Multiple Trauma. Abdominal Injuries. Wounds and Injuries. Risk Factors.

\section{INTRODUCTION}

$\mathrm{T}$ he management of blunt abdominal trauma (BAT) is challenging, intra-abdominal injuries are less obvious and the indications for laparotomy are not as clear as in penetrating trauma ${ }^{1}$. Currently, conservative treatment is the gold standard for solid organ injuries in hemodynamically stable patients. The suspected or confirmed hollow organs injury requires surgery².

Accurate and timely diagnosis of blunt intra-abdominal injury is a common dilemma. The accuracy of the physical examination has been questioned by many, while others have suggested that the best method of diagnosis is done through serial tests performed by an experienced surgeon $^{3}$. The abdomen is the third most affected region in blunt trauma and major traumatic injury may not be recognized quickly enough and it becomes a cause of preventable death ${ }^{4}$.

In order to minimize the mortality in cases of abdominal trauma, risk factors for mortality must be identified and systematically studied. In recent years, risk factors including gender, the time interval between injury and abdominal surgery, shock upon admission and head trauma were revealed ${ }^{5}$.

There is a lack of data in the literature related to blunt abdominal trauma that required laparotomy. The aim of our study was to identify risk factors associated with mortality in patients who underwent laparotomy after blunt abdominal trauma.

\section{METHODS}

This is a retrospective study of patients victims of blunt abdominal trauma that required emergency laparotomy in the Hospital do Trabalhador (HT), considered a teaching hospital and a reference in training human resources for healthcare ${ }^{6}$. It was selected all BAT victims undergone surgery (laparotomy) from March 2013 to January 2015, identified from the hospital surgery database. This study was aproved by the Ethics Committee of the Hospital do Trabalhador under the protocol number 44364215.6.0000.5225.

1. Departamento de Cirurgia da Universidade Federal do Paraná - PR - Brasil; 2. Serviço de Cirurgia Geral, Hospital do Trabalhador, Universidade Federal do Paraná - PR - Brasil; 3. Faculdade de Medicina, Universidade Federal do Paraná - PR - Brasil. 
All patients victims of penetrating trauma were excluded. It was carried out an analytic, case-control study comparing the group that was healed and the group that died, comparing the epidemiologic aspects, trauma mechanism, intra-operative findings, extra-abdominal injuries, laparotomy indications, trauma scores (Trauma and Injury Severity Score - TRISS), need for damage control surgery, reoperation and the outcomes. The data were collected, checked and submitted to statistical analysis. It was used the averages, standard deviation for the statistical analysis - chi-square test for categorical variables and the t-Studend test for numerical variables. It was considered $p<0,05$ as statistically significant.

\section{RESULTS}

A total of 86 patients were selected for the study. Of these, 54 obtained hospital discharge (63\%), 31 have evolved to death (36\%) and one patient was transferred and excluded from the study. Regarding the epidemiology, described in table 1, the age of the patients ranged from three to 82 years (average 32.72 years $\pm 15,93$ ), with 66 male $(77 \%)$. In both groups the majority of patients were male, healed with 42 men and 12 women and 24 men against seven women in the group of deaths, and majority in the fourth decade of life. The main mechanism of trauma for both groups was automobile accident ( $83 \%$ vs. $87 \%$ and $p=0,84)$ - including patients victims of motor vehicle collision (cars, pickup trucks, trucks), motorcycle crashes and auto pedestrian collisions. Others mechanisms of injury found: falls from a height ( 3 vs. 4 and $p=0,08$ ) and direct blunt abdominal trauma in six healed patients and in none of those who died ( 6 vs. 0 and $p=0,027$ ). The average hospital stay in the group of deaths was 4,6 days $( \pm 6,71)$, significantly $(p<0.05)$ lower than those patients who were discharged, who remain hospitalized on average 19 days $( \pm 23,6)(p=0,000791)$.

The main indication for surgical approach in nonsurvivors was hemodynamic instability - $61 \%$ vs. $38 \%$ (OR 2.4; C195\% 1.005-6.1 and $p=0,02$ ). In patients who have obtained hospital discharge, changes in computed tomography $(\mathrm{CT})$ were the main indication for laparotomy ( $50 \%$ vs. $31 \%$ and $p=0,47)$ - the main finding was free fluid in the abdominal cavity without solid organ injuries (70\% of CT). Other CT findings were the presence of solid organ injury and pneumoperitoneum (Table 2). Abdominal pain and signs of peritonitis were not indications for surgical intervention in any patient from the deaths group, but were indicative in $9 \%$ of patients healed $(\mathrm{OR}, 0.03 ; 95 \% \mathrm{Cl}$, $0.005-16$ and $p=0,04$ ).

Solid organ injury was higher in the death group $-80 \%$ vs. $48 \%$ (OR 4.4; C195\% 1.599-13.48 and $p=0,001$ ), and $61 \%$ of these had another intra abdominal injury associated against $25 \%$ of the group of healed (OR 3.0; CI95\%, 1.18-7.816 and $p=0,01)$. All six patients with isolated bladder injury were healed (OR 0; C195\% 0-13.5 and $p=0,02), 11$ patients in this group had only bowel injury and only one among the 18 patients with isolated hollow organ injury (duodenum, small bowel, colon and bladder) evolved to death (OR 0.07; CI95\% 0.003-0.4 and $\mathrm{p}=0,0001$ ).

Of patients who died, 96\% had severe extra abdominal injuries associated (head trauma, severe chest trauma, fracture of pelvis or femur, spine fracture in any segment), while in the healed group this figure represented $51 \%$ (OR 7.3; CI95\% 2.132-33.49 and $p=0,0003$ ). The result was also statistically significant when the TRISS was compared between groups, the healed group had an average of $91,7 \%$ and the death $46,3 \%(p=0,002)$.

There was a significant difference $(p<0,05)$ in outcome when compared the need for damage control surgery $-34 \%$ of patients required laparostomy in the first surgery, $45 \%$ of these have evolved to hospital discharge and 55\% died (OR 3.3; CI95\% 1.29-8.72 and $p=0,0099$ ) (Table 3).

\section{DISCUSSION}

The majority of the patients are young males and automobilist accident was the most common mechanism

Table 1 - Demographic Characteristics.

\begin{tabular}{lcr}
\hline Variables & Healed $(\mathrm{n}=\mathbf{5 4})$ & Death $(\mathrm{n}=\mathbf{3 1})$ \\
\hline Male & 42 & 24 \\
Female & 12 & 7 \\
Age $^{*}$ & 32.4 & 33.2 \\
Age $>$ 55 years & 5 & 3 \\
Mechanism of injury & & 27 \\
$\quad$ Automobile accident & 45 & 4 \\
$\quad$ Direct abdominal trauma & 3 & 0 \\
\hline Fall & 6 & \\
\hline
\end{tabular}

Source: Hospital do Trabalhador database.

*Mean age 
of trauma. In this study both groups, healed and death, had similar epidemiology in agreement with the literature, mostly young adult males ${ }^{3,7}$. This result is also found at the Hospital de Pronto Socorro de Porto Alegre by Espino et al. ${ }^{8}$ in Porto Alegre and in Santa Catarina by Kruel et al. ${ }^{9}$, they evaluated cases of abdominal trauma undergone laparotomy. It is known that age over 55 years old is a worse prognostic variable in trauma ${ }^{10,11}$, but in our study this was not found. Automobilist and motorcycles accidents were the most common mechanisms of trauma, but these were not related to the mortality. Farrath et al. pointed a higher incidence of abdominal lesions in victims of car crash, while victims of same level fall had a lower incidence ${ }^{4}$. We observed a negative association between direct abdominal trauma, such as aggression and falls, and deaths. These are low energy mechanisms of injury, therefore with less extra-abdominal related lesions, providing lower severity in the overall view of the patient.

Table 2 - Indication for laparotomy, injuries found.

\begin{tabular}{|c|c|c|c|}
\hline Variables & Healed $(n=54)$ & Death $(n=31)$ & $P$ \\
\hline \multicolumn{4}{|l|}{ Indication for laparotomy } \\
\hline Hemodynamic instability & 21 & 19 & 0.47 \\
\hline Abdominal pain & 5 & 0 & 0.058 \\
\hline$C T^{*}$ & 26 & 9 & 0.47 \\
\hline \multicolumn{4}{|l|}{ CT } \\
\hline Free fluid without solid organ injury & 23 & 7 & 0.62 \\
\hline Pneumoperitoneum & 3 & 2 & 0.1 \\
\hline Isolated solid organ injury & 7 & 6 & 0.27 \\
\hline Without CT & 21 & 15 & 0.39 \\
\hline \multicolumn{4}{|l|}{ Intraoperative findings } \\
\hline Absense of injury & 6 & 5 & 0.14 \\
\hline Isolated solid organs injury & 12 & 9 & 0.27 \\
\hline Multiple solid organ injuries & 8 & 7 & 0.19 \\
\hline Isolated bladder injury & 6 & 0 & 0.07 \\
\hline Isolated intestine injury & 11 & 1 & 0.15 \\
\hline \multicolumn{4}{|l|}{ Associated injuriest } \\
\hline Yes & 30 & 28 & \\
\hline No & 24 & 3 & 0.0009 \\
\hline TRISS & $91.7 \%$ & $46.3 \%$ & 0.002 \\
\hline Need for DCL $\neq$ & 13 & 16 & 0.0099 \\
\hline \multicolumn{4}{|l|}{ Days of hospitalization } \\
\hline Average & 19 & 12 & 0.0007 \\
\hline
\end{tabular}

Table 3 - $\quad$ Factors that influence the prognosis of blunt abdominal trauma victims with surgical approach.

\begin{tabular}{ll}
\hline Risk Factors (OR) & Good prognostic factors (OR) \\
\hline Important associated injuriest $(7,3)$ & Isolated hollow organ injury intraoperatively* $(0,007)$ \\
Solid organ injury $(4,4)$ & Abdominal pain or signs of peritonitis as indication for \\
Need for damage control laparotomy $(3,3)$ & laparotomy \\
Multiple intra abdominal injuries $(3,0)$ & Direct abdominal trauma \\
Lower TRISS $\neq$ & Hemodynamic instability as indication for laparotomy $(2,4)$ \\
\hline
\end{tabular}

Source: Hospital do Trabalhador database.

OR: Odds Ratio; *Bladder or intestine injury; tImportant associated injuries: Head trauma, thoracic trauma, spine fracture (any segment), fracture of pelvis or femur; \#Trauma and Injury Severity Score. 
In this study patients who did not survived have had a lower hospital stay time than patients who were discharged from hospital. Patients undergone exploratory laparotomies after blunt abdominal trauma die sooner because they are critically injured reflecting shorter hospital stay.

In the assessment of patients with suspected abdominal trauma the most common clinical presentation is the presence of hemorrhagic shock without apparent cause and the leading cause of death is the hypovolemic shock $^{12,13}$. The treatment for patients with hemodynamic instability and obvious signs of abdominal trauma is immediate surgical exploration ${ }^{12}$. We verified that patients victims of blunt abdominal trauma who go to laparotomy unstable have 2.4 times higher risk of death than those without circulatory changes, being a risk factor for mortality. According to Gad et al. hemodynamically unstable patients with abdominal lesions or suspected lesions that required abdominal laparotomy have a mortality rate higher than $56 \%$, especially those with systolic blood pressure below $60 \mathrm{mmHg}^{11}$. These patients therefore require fast and efficient handling in the prehospital and initial care, as well as greater attention in the postoperative period, since the aggressive surgical approach in patients with signs of shock should be maintained.

Patients with clinical signs of intra-abdominal injury - pain and signs of peritonitis - as an indication for surgery have a significant correlation with discharge. In general, patients with hollow viscera injury without major bleeding. Jones et al. have demonstrated that patients with no immediate indication for surgery and capable of monitoring with serial physical examination, that required intervention after blunt trauma showed signs or symptoms of injury within nine hours, and the vast majority in the first 60 minutes after arrival the emergency room ${ }^{14}$. We can conclude that when present, changes in physical examination on the patient are reliable explanations for intervention as well as better prognosis sign for the patient. The absence of these signals, however, does not exclude intra-abdominal injury ${ }^{15}$.

Most of the deaths in this study are related to multiple intra-abdominal injuries, predominantly solid organ injury, and $80 \%$ of deaths had another intra-abdominal injury associated, most other solid organ injury. These findings are in agreement with the study by Hildebrand et al., which evaluated a series of 342 blunt abdominal trauma undergoing laparotomy, and all patients who evolved to death had hepatic or splenic injury, even if in the smallest degree of severity ${ }^{16}$. Blunt abdominal trauma with multiple solid organ injury has higher mortality, greater need of ICU and days of hospitalization, and increased need for blood transfusions, which is in agreement with our study. The presence of any solid organ injury during surgery increases the risk of death by 4.4 times. The gold standard for treatment of solid organ injury is conservative and usually those in need of surgery have more severe injuries, which confer higher mortality.
We verified that isolated hollow viscera injury is a factor of good prognosis after blunt abdominal trauma. Even if the mandatory conduct in suspected hollow viscera injury is surgical intervention, the absence of other concomitant intra-abdominal injuries in trauma is consistent with a significantly lower risk of mortality. Although rare in blunt trauma the diagnosis and rapid management of patients with hollow viscera injuries remain compelling, a delay of more than 24 hours intervention is associated with higher mortality than those with immediate repair ${ }^{17,18}$.

There is a statistically significant difference between bladder isolated injury among groups studied in this sample. No patient who died had isolated bladder injury. A study of bladder injuries showed that those that required surgical repair of other abdominal organs beyond the bladder were at higher risk of mortality, especially elderly patients ${ }^{19}$. It is recommended that intraperitoneal bladder injury have immediate surgical repair and the extraperitoneal lesions will be reparied if a laparotomy is necessary to treat other abdominal injuries. Uncomplicated extraperitoneal bladder lesions can be managed with bladder catheter ${ }^{20}$

Extra-abdominal injuries add morbidity and mortality in blunt trauma, head trauma is a typically related factor as a cause of mortality in multiple trauma patients with blunt abdominal trauma ${ }^{21,22}$. Extra-abdominal injuries and their complications are the leading cause of late mortality in patients with multiple trauma who underwent laparotomy, as reported by Hildebrand et al. ${ }^{16}$ and Mohamed et al. ${ }^{21}$. Our study showed similar results, almost all deaths had potentially serious injuries associated with 7.3 times the risk of death. The results of our study confirm findings in the literature, indicating that the combination of abdominal, thoracic, pelvic or head injuries are associated with increased risk of adverse outcome.

Trauma score Injury Severity Score (ISS) greater than 35 was a factor related to mortality in blunt traumas with surgical indication by Fernandez et al. ${ }^{23}$. In our study we used the Trauma and Injury Severity Score (TRISS) based on the ISS and Revisited Trauma Score (RTS). Low TRISS also proved to be a risk factor for death in surgical patients after blunt abdominal trauma in our study. Despite of being a retrospective analysis of the likelihood of survival, TRISS index allow evaluation of the quality of the service provided by the trauma centers. This study can be used as source for this assessment in this group of patients.

In face of the need to promote the rapid control of hemorrhage and contamination caused by trauma and to ensure the adequate resuscitation is performed damage control laparotomy $(\mathrm{DCL})$. The aim of the $\mathrm{DCL}$, at first, is to preserve the life of the individual, allowing time for intensive treatment to restore their physiology, thus allowing the definitive surgical repair of injuries in a second time. Stalhschmidt et al. found that damage control surgery is indeed a measure that increases the survival rate of severely injured patients only if those patients have stabilization of 
their physiological parameters within the first 24 hours, if it does not occur, mortality rates remain high ${ }^{24}$. Independent factors affecting the survival of these patients include: Glasgow coma scale lower than eight and a base excess lower than $13.9 \mathrm{mEg} / \mathrm{L}^{5}$. In our study the need for damage control laparotomy is a major risk factor for death after blunt abdominal trauma. They are more severe patients who it was chosen for an immediate approach due to greater risk injuries and a scheduled reoperation when improvement of physiological parameters. The mortality found in our study was 36\%, lower than in studies with similar samples between 38.3 and $41.9 \%^{16,21}$. These studies however considered only patients with ISS greater than 18 and excluded patients with negative laparotomy. Our study aimed to find risk factors for bad and good prognosis for the group of patients victims of blunt abdominal trauma undergone exploratory laparotomy. Although we have a good number of subjects, it was a small sample to define with precision all the risk factors.

In conclusion, the groups of healed and death showed no significant statistical difference in epidemiology and mechanism of injury. From this study, we can say that risk factors for death to blunt abdominal trauma who require laparotomy include: hemodynamic instability as an indication for laparotomy, presence of solid organ injury, multiple intraabdominal injuries, necessity of damage control laparotomy, severe injury associated as head trauma, severe chest trauma, pelvic or femoral fractures, and low trauma index. Among the good prognostic factors we noticed a tendency to factors such as direct abdominal trauma, pain or peritonitis as surgical indication and the finding of isolated hollow viscera injury during surgery (bladder or small intestine).

\title{
R E S U M O
}

\begin{abstract}
Objetivo: identificar fatores de risco para óbito em pacientes submetidos à laparotomia exploradora após trauma abdominal contuso. Métodos: estudo retrospectivo, caso-controle, no qual foram revisados prontuários dos pacientes vítimas de trauma contuso submetidos à laparotomia. Foram avaliados: variáveis epidemiológicas, mecanismo de trauma, lesões anatômicas das vísceras abdominais, lesões associadas, necessidade de operação para controle de danos reoperação e desfecho. Resultados: dos 86 pacientes, $63 \%$ foram curados, 36\% foram a óbito e um paciente foi excluído do estudo. Ambos os grupos possuíam epidemiologia e mecanismo de trauma semelhantes, predominantemente adultos jovens do sexo masculino, vítimas de acidente automobilístico. $A$ maioria dos casos que evoluíram a óbito teve instabilidade hemodinâmica como indicação de laparotomia - $61 \%$ contra 38\% do outro grupo. A presença de lesão de víscera maciça foi maior no grupo óbitos - $80 \%$ vs. 48\%, e $61 \%$ destes tinham outra lesão abdominal associada contra $25 \%$ dos curados. Dos pacientes que faleceram, $96 \%$ apresentavam lesões graves associadas. Pacientes que necessitaram de cirurgia de controle de danos tiveram maior taxa de mortalidade. Apenas um de 18 pacientes com lesão de víscera oca isolada evoluiu a óbito. A média do escore de trauma TRISS dos curados (91,7\%) foi significativamente maior do que a dos óbitos (46,3\%). Conclusão: os fatores de risco para óbito encontrados para vítimas de trauma abdominal fechado que necessitam de laparotomia exploradora são: instabilidade hemodinâmica como indicação para laparotomia, presença de lesão de víscera maciça, múltiplas lesões intra-abdominais, necessidade de cirurgia de controle de danos, lesões graves associadas e índice de trauma baixo.
\end{abstract}

Descritores: Traumatismo Múltiplo. Traumatismos Abdominais. Ferimentos e Lesões. Fatores de Risco.

\section{REFERENCES}

1. Starling SV, Drumond DAF. Tratamento não operatório de 1.768 pacientes portadores de lesões das vísceras maciças abdominais por trauma contuso atendidos no Hospital João XXIII. Rev Med Minas Gerais. 2014;24(4):432-40.

2. Ribas-Filho JM, Malafaia O, Fouani MM, Justen MS, Pedri LE, Silva LMA, et al. Trauma abdominal: estudo das lesões mais frequentes do sistema digestório e suas causas. $A B C D$, arq bras cir dig. 2008;21(4):170-4.

3. Lima SO, Cabral FLD, Pinto Neto AF, Mesquita FNB, Feitosa MFG, Santana VR. Avaliação epidemiológica das vítimas de trauma abdominal submetidas ao tratamento cirúrgico. Rev Col Bras Cir. 2012;39(4):302-6.

4. Farrath S, Parreira JG, Perlingeiro JAG, Soldá SC, Assef JC. Fatores preditivos de lesões abdominais em vítimas de trauma fechado. Rev Col Bras Cir. 2012;39(4):295-301.

5. Wang SY, Liao CH, Fu CY, Kang SC, Ouyang CH, Kuo IM, et al. An outcome prediction model for exsanguinating patients with blunt abdominal trauma after damage control laparotomy: a retrospective study. BMC Surg. 2014;14:24.
6. Hospital do Trabalhador [homepage na Internet]. Tipos de Atendimento no Pronto Socorro [acesso em 15 jan 2015]. Disponível em: http:www. hospitaldotrabalhador.saude.pr.gov.br.

7. Leite S, Taveira-Gomes A, Sousa H. Lesão visceral em trauma abdominal: um estudo retrospetivo. Acta Med Port. 2013;26(6):725-30

8. Espino JAR, Dominguez LCA, Barthelemy IR, Hernández IG, Ojeda MJO. Traumas abdominales. Experiência en un servicio cirugia general, 1986 a 1993. Rev Cubana Cir. 2002;(2):24-9.

9. Kruel NF, Oliveira VL, Oliveira VL, Honorato RD, Di Pinatti B, Leão FR. Perfil epidemiológico de trauma abdominal submetido à laparotomia exploradora. ABCD, arq bras cir dig. 2007;20(2):10610

10. Berg RJ, Okoye O, Teixeira PG, Inaba K, Demetriades D. The double jeopardy of blunt thoracoabdominal trauma. Arch Surg. 2012;147(6):498-504.

11. Gad MA, Saber A, Farrag S, Shams ME, Ellabban GM. Incidence, patterns, and factors predicting mortality of abdominal injuries in trauma patients. N Am J Med Sci. 2012;4(3):129-34 
12. Pereira Júnior GA, Lovato WJ, Carvalho JB, Horta MFV. Abordagem geral trauma abdominal. Medicina. 2007;40(4):518-30.

13. Sánchez Portela CA, Delgado Fernández JC, Robaina Arias LE, Rodríguez Lorenzo S, Díaz Arteaga Y. Morbilidad y mortalidad por traumatismo abdominal (2002 a 2004). Rev Cubana Cir [periódico na Internet]. 2007 [acessado em 15 jan 2015];46(3). Disponível em: http://scielo.sld.cu/scielo.php?script=sci_arttext\&pid=S003474932007000300007\&lng=es.

14. Jones EL, Stovall RT, Jones TS, Bensard DD, Burlew CC, Johnson JL, et al. Intra-abdominal injury following blunt trauma becomes clinically apparent within 9 hours. J Trauma Acute Care Surg. 2014;76(4):1020-3.

15. Nishijima DK, Simel DL, Wisner DH, Holmes JF. Does this adult patient have a blunt intra-abdominal injury? JAMA. 2012;307(14):1517-27.

16. Hildebrand F, Winkler M, van Griensven M, Probst C, Musahl V, Krettek $C$, et al. Blunt abdominal trauma requiring laparotomy: an analysis of 342 polytraumatized patients. Eur J Trauma. 2006;32(5):430-8.

17. Swaid F, Peleg K, Alfici R, Matter I, Olsha O, Ashkenazi I, et al. Concomitant hollow viscus injuries in patients with blunt hepatic and splenic injuries: an analysis of a National Trauma Registry database. Injury. 2014;45(9):1409-12.

18. Watts DD, Fakhry SM; EAST Multi-Institutional Hollow Viscus Injury Research Group. Incidence of hollow viscus injury in blunt trauma: an analysis from 275,557 trauma admissions from the EAST multiinstitutional trial. J Trauma. 2003;54(2):289-94. Erratum in: J Trauma. 2003;54(4):749.

19. Deibert CM, Spencer BA. The association between operative repair of bladder injury and improved survival: results from the National
Trauma Data Bank. J Urol. 2012;186(1):151-5. Erratum in: J Urol. 2012;187(5):1938.

20. Gomez RG, Ceballos L, Coburn M, Corriere JN Jr, Dixon CM, Lobel $B$, et al. Consensus statement on bladder injuries. BJU Int. 2004;94(1):27-32.

21. Mohamed AA, Mahran KM, Zaazou MM. Blunt abdominal trauma requiring laparotomy in poly-traumatized patients. Saudi Med J. 2010;31(1):43-8.

22. Wudel JH, Morris JA Jr, Yates K, Wilson A, Bass SM. Massive transfusion: outcome in blunt trauma patients. J Trauma. 1991;31(1):1-7.

23. Domínguez Fernández E, Aufmkolk M, Schmidt U, Nimtz $K$, Stöblen F, Obertacke $U$, et al. Outcome and management of blunt liver injuries in multiple trauma patients. Langenbecks Arch Surg. 1999;384(5):453-60.

24. Stalhschmidt CMM, Formighieri B, Lubachevski FL. Controle de danos no trauma abdominal e lesões associadas: experiência de cinco anos em um serviço de emergência. Rev Col Bras Cir. 2006;33(4):215-9.

Received on 15/01/2015

Accepted for publication 20/03/2015

Conflict of interest: none.

Source of funding: none.

Address for correspondence:

Melissa Mello Mazepa

E-mail: melissa.mazepa@gmail.com 